How to cite: Popa, M.C., Diaconu, D.C. (2019) Effects of Deforestation on Flooding in the Moldova River Basin. 2019 "Air and Water - Components of the Environment" Conference Proceedings, Cluj-Napoca, Romania, p. 129136, DOI: 10.24193/AWC2019_13.

\title{
EFFECTS OF DEFORESTATION ON FLOODING IN THE MOLDOVA RIVER BASIN
}

\author{
Mihnea Cristian POPA ${ }^{I_{凶}, \text { Daniel Constantin DIACONU }}{ }^{2}$
}

DOI: $10.24193 / A W C 2019 \_13$

\begin{abstract}
Effects of deforestation on flooding in the Moldova river basin. Given the correlation between deforestation and floods and the many negative consequences of these two factors, this paper aims to identify the areas vulnerable to the risks of flash flooding and the influence of deforestation on this phenomenon based on the flood recordings from 2005 to 2016 and the forest changes from 2000 to 2016 . The high frequency of flooding events is affecting the economic development of the area, yearly almost half of the territorial-administrative units that overlap the area of the basin are hit by floods. The methodology was applied for the Moldova river basin, located in the northern part of Romania by computing the Flash Flood Potential Index (FFPI). The results are used to determine the flash flood potential and identify how the loss of forest affected the territorial-administrative units with the most frequent flooding events.
\end{abstract}

Keywords: flash flood, deforestation, flash flood potential index (FFPI), hydrological modelling, GIS

\section{INTRODUCTION}

The relationship between deforestations and flooding is a very debated subject, being often put into the light of either a myth or reality. Deforestation is one of the oldest human activities, one of the main reasons being the change of land use. Besides the loss of biodiversity, other factors generated by deforestation are landslides and the increase of $\mathrm{CO}_{2}$ in the atmosphere. Deforestation not only has an important impact on the environment but also on economy and society. Although the main factor that generates flash floods is a climatic one, the hydrological response is a very different one, which depends heavily on the geographical characteristics of the area, such as the slope, soil texture, land use, rock permeability, etc. (Sorocovschi, 2003). An important change in the normal run off of water on slopes is caused by deforestation. Previous studies (Suryatmojo, 2014, FAO, 2011) show us that the loss of forest increases soil erosion and the flow of streams, reduces water quality and soil fertility.

\footnotetext{
${ }^{1}$ University of Bucharest, Faculty of Geography, Centre for Integrated Analysis and Territorial Management, e-mail: popamihneacristian@gmail.com

${ }^{2}$ University of Bucharest, Faculty of Geography, Centre for Integrated Analysis and Territorial Management, e-mail: ddcwater@yahoo.com
} 
The article aims to apply the Flash Flood Potential Index (FFPI) and compare the results obtained with forest changes in our study area as well the frequency of flood produced during the period $2005-2016$.

\section{DATA AND METHODS}

\subsection{Data used}

The analysis conducted in this study is based on a series of geospatial and hydrological data, compiled into a single database. We used several datasets and existing maps in order to be able to extract all the information necessary to calculate the Flash Flood Potential Index and see whether there is a relationship between the deforestations in the Moldova river basin and its floods, therefore we used the following: the EU-DEM from the European Environment Agency, the Global Forest Change 2016 dataset from the University of Maryland, CORINE Land Cover 2012 dataset, the Topographical map of Romania 1: 25 000, the Romanian Water Cadaster and the Soil and the Geological maps of Romania 1: 200 000. All vector data was transformed into a raster format using ArcGIS 10.5.1 and all raster data was resampled to a cell resolution of $30 \mathrm{~m}$.

\subsection{Methods}

The Moldova river basin is located in the northern part of Romania and is a left tributary to the Siret river. The basin has an area of $4353 \mathrm{~km}^{2}$ and is overlapping 3 counties: Suceava, Neamt, Iași and 73 territorial-administrative units (UAT).

The river springs from the Lucina peak, at an altitude of $1587 \mathrm{~m}$ and drops 1407 $\mathrm{m}$ in elevation from its source to its mouth, the Siret river, at $180 \mathrm{~m}$ near the city of Roman. Out of all the rivers from the upper basin of Siret, Moldova is the only river which doesn't have any hydrotechnical constructions or any accumulation lakes. The river has a slope of $3.76 \%$ or $0.037 \mathrm{~m} / \mathrm{km}$, whilst the basin has an average slope of $9.8^{\circ}$ and an average height of $672 \mathrm{~m}$. The basin's elongated shape is indicated by the circularity ratio of 0.23 , which was determined using the following equation (Eq. 1) developed by Miller (1953) where $R_{c}$ represents the circularity ratio, $S$ the surface in $\mathrm{km}^{2}$ and $\mathrm{P}$ the perimeter in $\mathrm{km}$.

$$
R_{C}=\frac{4 * \pi * S}{P^{2}}
$$

The main climatic characteristics of the study area show us that the climate is an eastern European one, with oceanic and Baltic influences in the upper basin and continental ones in the lower basin. The annual mean of temperature is $7,7^{\circ} \mathrm{C}$ and an annual average of precipitations of $671,8 \mathrm{~mm} / \mathrm{m}^{2}$. (Chiriloaei, 2012) The discharge regime shows high values in the months of spring and a minimum in autumn (Croitoru, 2014).

The data extracted from the CORINE Land Cover 2012 dataset indicates the fact that almost half of the basin's surface is covered with forests (49\% or 212.351 ha), arable land $27 \%$ and human settlements only $7 \%$. 
The information regarding the forest areas was extracted from the Global Forest Change dataset, available on the website of the Department of Geographical Sciences of the University of Maryland. The dataset gives us a global overview of the forest changes over the period of $2000-2016$ in a raster format (GeoTIFF). The gain and the loss areas were encoded as 1 (loss or gain - white) and 0 (no loss or no gain - black) (Hansen, 2013). The loss and gain areas were extracted from the raster images in a vector format using the Raster to Polygon conversion tool of ArcGIS. The outputs are identified in figure 1 and figure 2, showing the areas with forest changes, loss or gain of area.

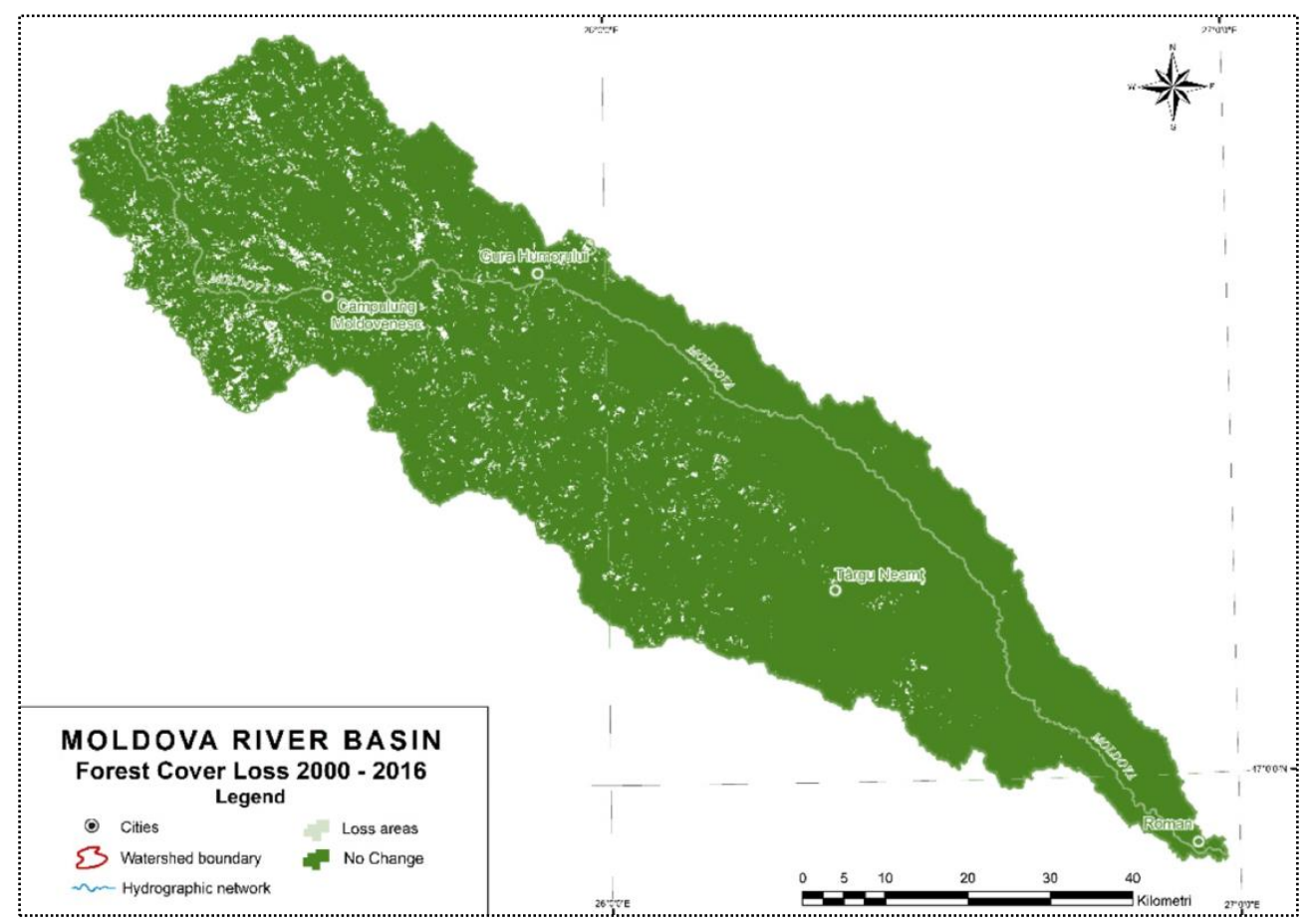

Fig. 1. The forest cover loss 2000 - 2016

The Moldova river basin is known for its high frequency of flooding events, which occur almost yearly. Based on the historical data recordings from 2005 to 2016 from the National Institute of Hydrology and Water Management, 2010 was the most catastrophic year where 57 of its 73 administrative-territorial units were flooded, whereas in 2015 only 5 of them were flooded. Other years with a high number of flooding events were: 2005 - 53 flooded UAT's, 2016 - 47, 2006 - 46 and 2008 - 45. Based on a simple observation of the flood recordings over the 11-year span, on an average 33 administrative territorial units are flooded annually, meaning $45 \%$ of its UAT's.

Flash floods represent a brutal form of flood events, being more difficult to predict in due course of time, causing significant economic and human losses due to the short reaction time available (Grecu, 2009). In addition to the direct effects to the local economy and inhabitants, floods also have a negative environmental impact (Șerban 
et al, 2010). Flash floods are the result of the interaction between a series of natural and anthropogenic factors specific to an area. The Flash Flood Potential Index (FFPI) was developed by Smith (2003) as a method for identifying the areas with a high potential for flash floods. The index (FFPI) was developed as part of a US-funded "Western Region Flash Flood Project", which was later tested in other regions. Its purpose is to represent the flood potential of a hydrographic basin, based on a series of physical-geographic features the sub-basins where they can happen.

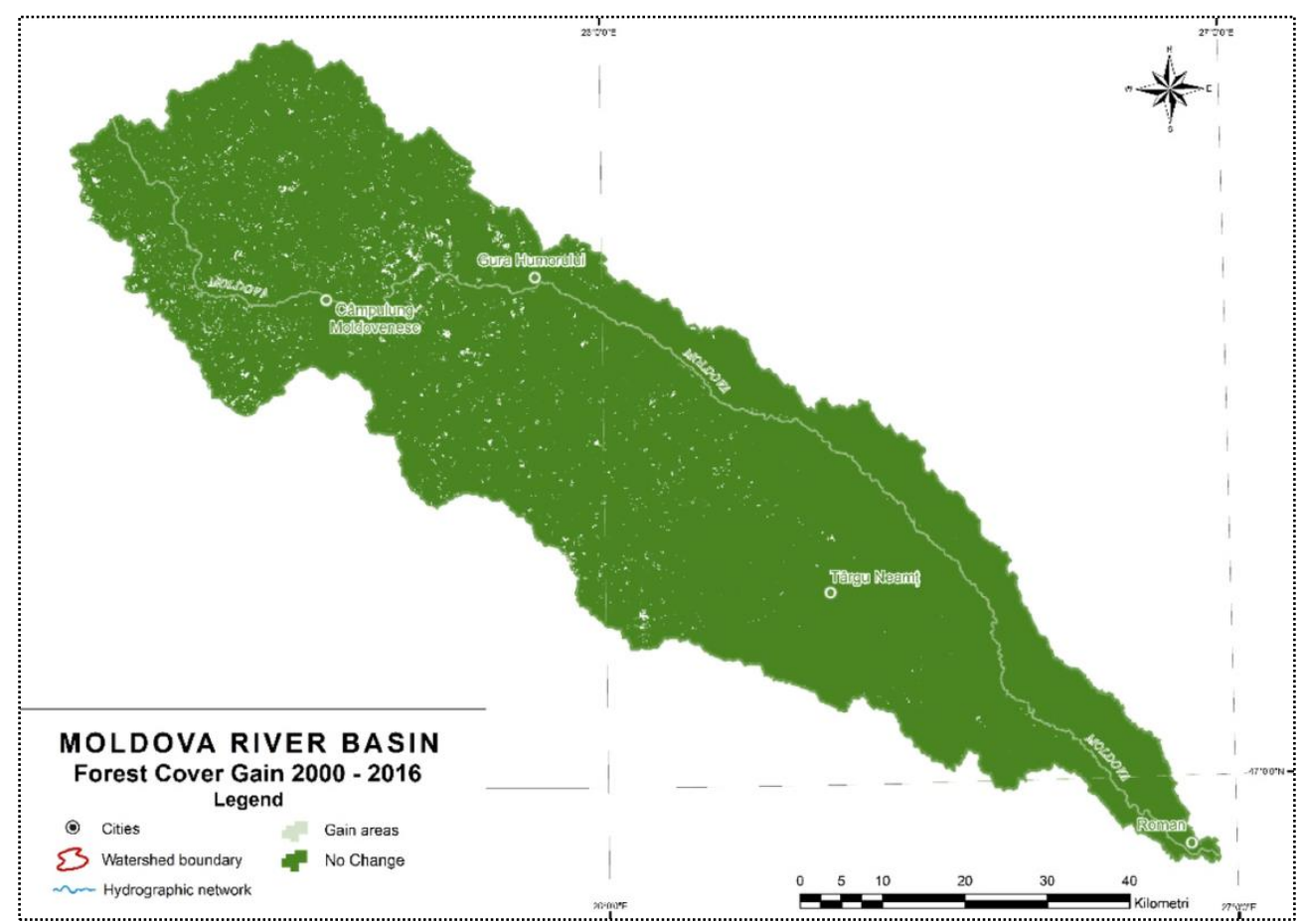

Fig. 2. The forest cover gain 2000 - 2016

The calculation of the Flash Flood Potential Index was realized by selecting six geographical factors which have a direct influence on this phenomenon, such as: Slope, Profile Curvature, Slope Aspect, Hydrologic Soil Groups (HSG), Potential Maximum Retention and the Lithology. Most of these factors were extracted from the Digital Elevation Model (based on the EU-DEM dataset): slope, profile curvature, slope aspect. The hydrologic soil groups were derived from the Soil map of Romania 1: 200000 based on their texture. The lithologic data was extracted from the Geological Map of Romania 1: 200 000. In order to obtain all the factors necessary to calculate the FFPI, we needed to determine the Curve number $(\mathrm{CN})$ to be able to compute the Potential Maximum Retention. The Potential Maximum Retention represents the infiltration that occurs only after the run off process begins (Urban Hydrology for Small Watershed, 1986). The curve number is used to determine the run off process caused by precipitations (National Engineering Handbook, 2009; Sumarauw et al., 2012). The run off curve number is a hydrological 
parameter used to predict the potential water run-off and is obtained from the soil type and land use. The Potential Maximum Retention (S) was obtained using the following equation (Eq. 2) where $\mathrm{S}$ is the storage depth in $\mathrm{mm}$ and $\mathrm{CN}$ the curve number (Singh and Frevert, 2002):

$$
S=\frac{25400}{C N}-254
$$

Having all the chosen factors generated, using the built-in Raster Reclassify tool of ArcGIS, we reclassified them into five classes. The equation (Eq. 3) to calculate the Flash Flood Potential Index uses an equal weighting scheme for each of the six factors and was calculate using the Raster Calculator tool, where M - Slope $\left({ }^{\circ}\right), \mathrm{Pc}$ - Profile Curvature, Sa - Slope Aspect, HSG - Hydrologic Soil Groups, S - Potential Maximum Retention, $\mathrm{Li}$ - Lithology. The output is identified in figure 3.

$$
F F P I=M+P c+S a+H S G+S+L i
$$

\section{RESULTS AND DISCUSSIONS}

Romania has large areas of continuous virgin forests characteristic to the European temperate zone, unfortunately with high deforestation rates especially in the Subcarpathian and the Carpathian Mountains. Our study area is located in the northeastern development region of Romania, having the highest rates of deforestation.

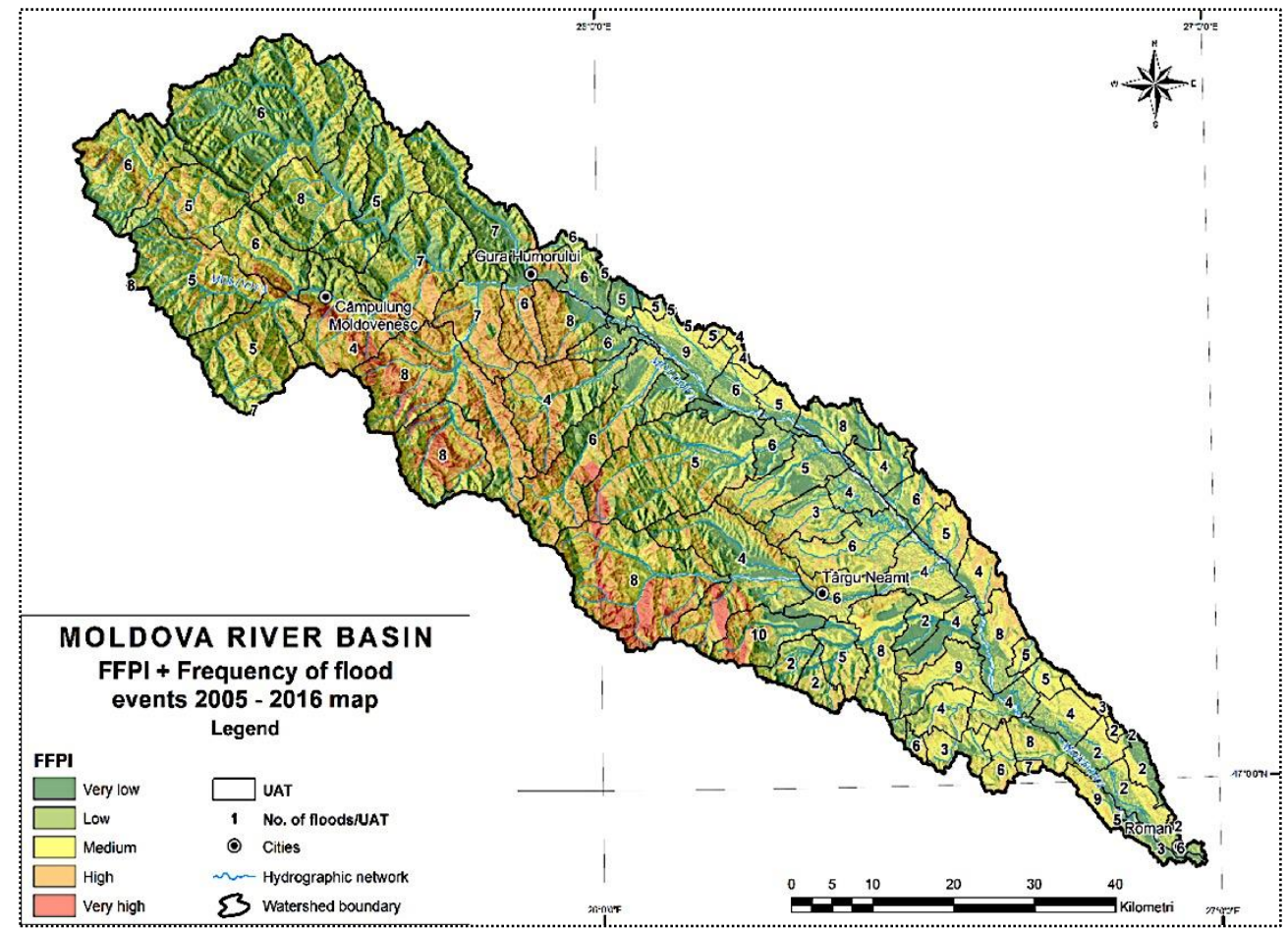

Fig. 3. The Flash Flood Potential Index (FFPI) map and the frequency of flood events 2005 - 2016 
During the socialist rule of Romania, forests were state-owned, but after the fall of it in 1989, the following period was characterized by an increase in private-owned lands which intensified the logging activity and declined forest harvesting (Andronache et al, 2017; Pintilii et al, 2017). The analysis conducted on the images obtained from the Global Forest Change dataset, show us that in our study area the deforestation rates are not constant and years with the highest rates were 2002, 2005, 2007, 2010 and 2012. These years were not only characterized by a loss in forest cover but also by massive floods, in 2005 around $72 \%$ of the territorialadministrative units were flooded, in $2007-41 \%$ and $2008-61 \%, 2010-78 \%$ (the most catastrophic). In the year of 2012 only $19 \%$ of its territorial-administrative units were flooded but the following year $46 \%$ of its UAT's were affected by floods.

During the recent period of time the critical rate of the deforested area in relation to the surface of the basin has not been reached. Most of the surface of our hydrographic basin is located in the county of Suceava, being one of the Romanian counties with the most deforested areas, fact validated by the large deforested areas in our upper basin.

The Flash Flood Potential Index (FFPI) was obtained from the selection of six geographical factors, all with a direct influence on the run-off processes. The mathematical equation used an equal weighting interval for each factor. According to the methodology described earlier, we obtained 2 maps (fig. 3 and fig. 4), which show us the areas vulnerable to flash floods, the number of floods recorded in from 2005 to 2016 per territorial-administrative unit and the deforested areas from 2000 to 2016.

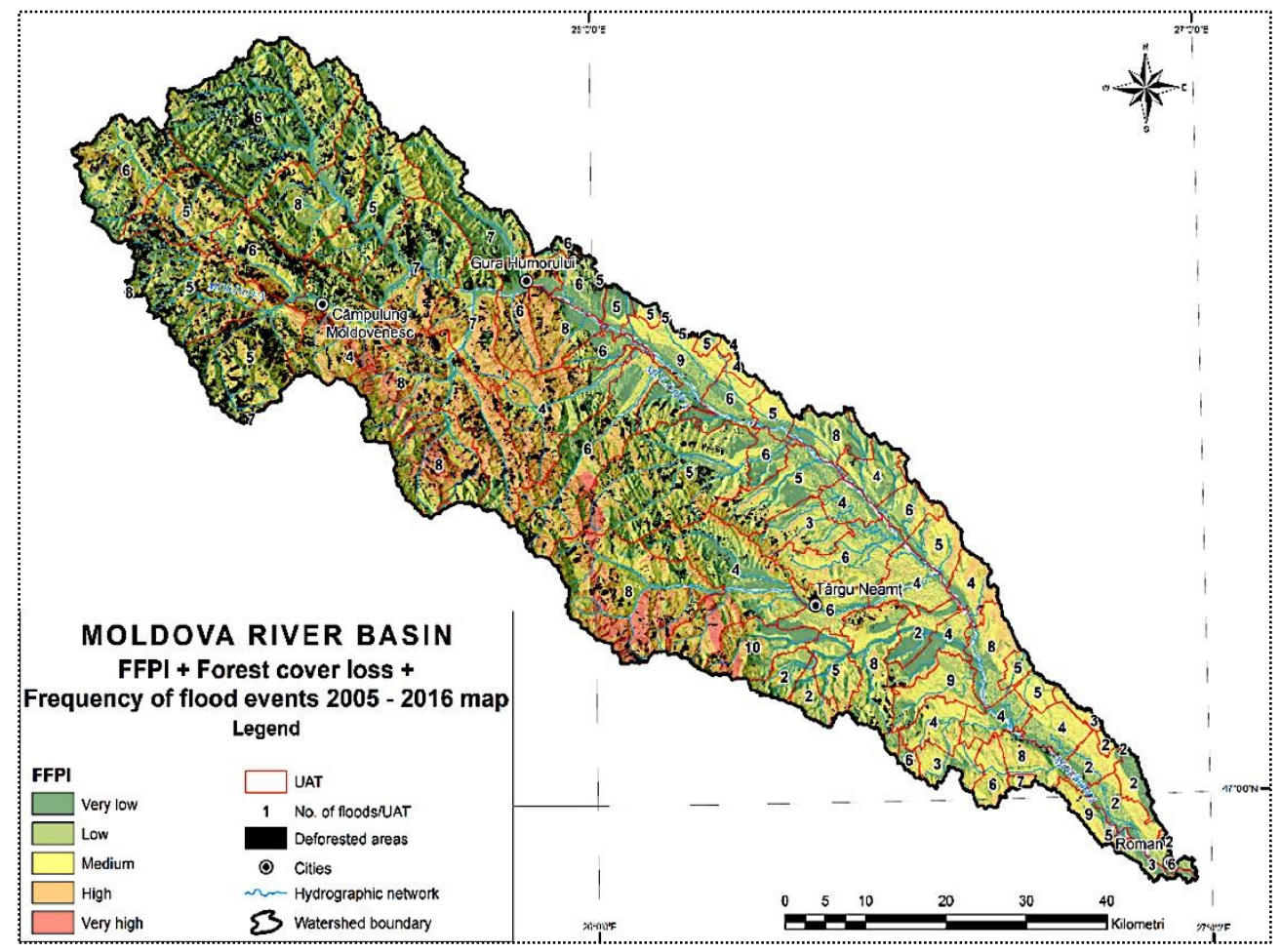

Fig. 4. The FFPI, forest cover loss (2000-2016) and the frequency of flood events map 
The result of the FFPI validates us that the territorial-administrative units that recorded frequent flooding events in the period of time mentioned earlier do overlap over the areas with medium, high and a very risk to flash floods. The areas with a high and a very high risk are located in the central part of our hydrographic basin where most of the UAT's have recorded from 4 to 10 flooding events in the 11-year span. We overlapped the deforested areas over the FFPI (fig. 4) and most of the territorialadministrative units located in the upper basin where massive deforestations occurred recorded between 5 to 8 flooding events. Most of that area has a medium risk to flash floods. The area with a high and very high risk to flash floods also recorded significant deforestation, contributing to the frequent flooding events and validating the effect of deforestation on the frequency of floods in our study area.

\section{CONCLUSIONS}

The analysis carried out in this study used modern computing techniques alongside open-source data, accessible to everyone at no cost. This study can identify the areas with a high flood risk and can determine the relationship between the land use and the frequency of floods. The high frequency of floods in the Moldova river basin is observed in the sub-basins with high rates of deforestation and in some cases this tendency decreases due to the fact that the critical rate of deforestation has not been reached.

Our objective is to determine how the weight of influence of the physicalgeographic factors and land use play a role in triggering flash floods, given the degree of afforestation, extreme climatic events and the endowment with hydrotechnical constructions of the basins.

The development of this methodology can support the development of a second phase of developing a flood hazard and risk map for Romania in line with the Directive 2000/60/ EC.

\section{REFERENCES}

1. Andronache I., Fensholt R., Ahammer H., Ciobotaru A.-M., Pintilii R.-D., Peptenatu D., Drăghici C.-C., Diaconu D.C., Radulović M., Pulighe G., Azihou A.F., Toyi M.S., Sinsin B. (2017) Assessment of Textural Differentiations in Forest Resources in Romania Using Fractal Analysis. Forests, 8, 54

2. Barbu O., Stănilă C. (2016) Services of General Interest and Territorial Sustainability in Romania, Annals of Valahia University of Târgoviște, Geographical Series, 16(2), 69-74

3. Chiriloaiei F. A., (2012) Analiza cantitativă a modificărilor albiei râului Moldova în sectorul extracarpatic, PhD Thesis, Facultatea de Geografie și Geologie, Universitatea „Alexandru Ioan Cuza”, Iași

4. Croitoru A.-E., Minea I. (2014) The impact of climate changes on rivers discharge in Eastern Romania, Thor Appl Climatol., DOI 10.1007/s00704-014-1194-z

5. European Environmental Agency: www.eea.europa.eu 
6. FAO (2011) Assessing Forest Degradation: Towards the development of globally applicable guidelines, FAO Forest Resources Assessment Working Paper, 177

7. Grecu F. (2009), Hazarduri şi riscuri naturale, $\mathrm{Cu}$ adăugiri. Ediţia a IV-a, Edit. Universităţii din Bucureşti, 303

8. Hansen M. C., Potapov P. V., Moore R., Hancher M., Turubanova S. A., Tyukavina A., Thau D., Stehman S. V., Goetz S. J., Loveland T. R., Kommareddy A., Egorov A., Chini L., Justice C. O., Townshend J. R. G. (2013) "High-Resolution Global Maps of 21st-Century Forest Cover Change." Science, 342, 850-53. Data available on-line from: http://earthenginepartners.appspot.com/science-2013-global-forest

9. ***, Geological Map, Institutul de Geologie al României: www.igr.ro

10. Pintilii R.-D., Andronache I., Diaconu D.C., Dobrea R.C., Zeleňáková M., Fensholt R., Peptenatu D., Drăghici C.-C., Ciobotaru A.-M. (2017) Using Fractal Analysis in Modeling the Dynamics of Forest Areas and Economic Impact Assessment: Maramureș County, Romania, as a Case Study. Forests, 8, 25

11. Șerban Gh., Selagea H., Máthe E., Hognogi Gh. (2010) Efecte produce de viitura din 20.06.2006 în bazinul râului Ilișua (Bazinul Someșul Mare), Aerul și Apa. Componente ale Mediului, Cluj-Napoca, 156-165

12. Smith G. (2003) Flash Flood Potential: Determining the hydrologic response of FFMP basins to heavy rain by analyzing their physiographic characteristics

13. Sorocovschi V. (2003) Complexitatea teritorială a riscurilor şi catastrofelor, Riscuri şi catastrofe, vol.II, Editor Sorocovschi V., Edit. Casa Cărţii de Ştiinţă, Cluj-Napoca. $39-48$.

14. Suryatmojo H. (2014) Rainfall-runoff investigation of pine forest plantation in the upstream area of Gajah Mungkur reservoir, Procedia Environmental Sciences, 28, 307-314

15. United States Department of Agriculture, Natural Resources Conservation Service (1986) Urban Hydrology for Small Watersheds, TR-55, 2-11

16. Zeleňáková M., Dobos E., Kováčová L., Vágo J., Abu-Hashim M., Fijko R., Purcz P. (2018) Flood vulnerability assessment of Bodva cross-border river basin, Acta Montanistica Slovaca, 23, 1, 53-61

17. Zeleňáková M., Gaňová L., Purcz P., Horský M., Satrapa L. (2017) Mitigation of the Adverse Consequences of Floods for Human Life, Infrastructure, and the Environment, Natural Hazards Review, 19, 4 